\title{
Effect of Wilting and Silage Additives on Silage Quality of Lucerne, Red Clover and Legume-Grass- Mixtures
}

\author{
Weiß Kirsten ${ }^{1 *}$ and Kalzendorf Christine ${ }^{2}$ \\ ${ }^{1}$ Humboldt Universität zu Berlin, Germany \\ ${ }^{2}$ Chamber of Agriculture Lower-Saxony, Germany
}

Submission: March 13, 2017; Published: March 30, 2017

*Corresponding author: Weiß Kirsten, Humboldt Universität zu Berlin, Albrecht Daniel Thaer- Institute, Berlin, Germany,

Email: kirsten.weiss@agrar.hu-berlin.de

\begin{abstract}
Lucerne (Medicago sativa), red clover (Trifolium pratense) and the mixtures with grass are regarded difficult to ferment based on low contents of water-soluble carbohydrates (WSC) and nitrate as well as high buffering capacity (BC). The objective of this laboratory ensiling trial was to investigate the effects of 24,48 and 72 hours wilting on dry matter (DM) as well as content of yeasts and lactic acid bacteria (LAB). Furthermore, the effects of chemical and biological additives on silage quality were investigated regarding the concentration of lactic acid, acetic acid and butyric acid, ethanol and ethyl esters depending on the level of wilting in ensiling material. With extended wilting period, the contents of WSC decreased, whereas the contents of yeasts and LAB increased. A lower range of DM is associated with a higher risk of butyric acid formation, which requires the addition of chemical additives against clostridia activity. The results demonstrate the occurrence of volatile organic compounds (VOC), especially ethanol and ethyl esters, in legume silages. The DM content and silage additives affect the concentrations of ethanol, acids and esters. Elevated levels of ethanol and esters occur in silages with low DM. For the reduction of ethanol and ester formation, chemical additives against yeasts and bacteria are necessary.
\end{abstract}

Keywords: Legumes; Silage quality; Volatile organic compounds; Esters

\section{Introduction}

Legumes are crops difficult to ensile due to low contents of water-soluble carbohydrates (WSC), buffering capacity (BC) and nitrate. However, they play an important role in supplying nitrogen in rotational food production systems and may have a high nutritive value, especially high contents of crude protein. The objective of this study was to examine the silage management factors such as wilting and silage additives on legume and legume/grass/mixture silage quality in combination with the incidence of VOC. Weiß \& Auerbach [1] postulated that esters can be frequently found in maize, whole crop wheat and sorghum silages and also in grass silages and that ester concentrations are strongly correlated with the ethanol concentration and silage $\mathrm{pH}$.

\section{Materials and Methods}

Lucerne, red clover and the mixtures with grass were harvested on $1^{\text {st }}$ of June 2015 near Oldenburg, Germany, chopped to a theoretical particle length of $4 \mathrm{~cm}$ and wilted for 24,48 and 72 hours. Fresh and wilted ensiling material (EM), with and without any additives, were filled into $1.5 \mathrm{~L}$ glass jars and stored for 90 days under anaerobic conditions at $20^{\circ} \mathrm{C}$. All treatments were done in triplicates. Each crop received the ensiling treatments of no additive (Control), different commercial products of lactic acid bacteria (LAB 1, LAB 2) with inoculation rates of $105 \mathrm{cfu}$ $\mathrm{g}^{-1} \mathrm{FM}$, and commercial chemical products with a mixture of nitrite, hexamine and/or benzoate (Salt). Herbage (EM) with DM contents of $<400 \mathrm{~g} \mathrm{~kg}^{-1}$ was treated with products of aimof-acting (WR) 1a, 1b or 1c according to DLG (2011), EM with $\mathrm{DM}>400 \mathrm{~g} \mathrm{~kg}^{-1}$ with products of WR 2 . The contents of DM, LAB, yeasts, WSC and nitrate were analysed according to standard methods (LUFA). Silage analyses were conducted in aqueous extracts of frozen silages as described by Weiss \& Auerbach [1]. Lactic acid (LA) was analysed by HPLC. Fermentation acids, alcohols and esters were determined by GC. Statistical analyses were performed with SAS 9.3. For treatment comparisons, the analysis of variance was used. 


\section{Results and Discussion}

Table 1: Effects of silage additives on contents of ethanol and esters in silages of legume depending on ensiling material, characterized by the parameters of ensilability, FC, WSC.

\begin{tabular}{|c|c|c|c|c|c|c|c|c|c|}
\hline \multicolumn{4}{|c|}{ Parameters of Ensilability } & \multicolumn{5}{|c|}{ Ethanol in gkg $^{-1} \mathrm{DM}$} & \multirow[b]{2}{*}{$\left.\mathbf{P}^{5}\right)$} \\
\hline & $\left.\mathbf{D M}^{2}\right)$ & $\mathrm{FC}^{3}$ ) & $\mathrm{WSC}^{4}$ ) & Control & LAB1 & LAB2 & Salt & SEM & \\
\hline \multicolumn{10}{|c|}{ Lucerne (Lu) } \\
\hline $24 \mathrm{~h}$ & 232 & 28 & 39 & $10.8^{\mathrm{a}}$ & $8.8^{\mathrm{ab}}$ & $8.2^{\mathrm{b}}$ & $3.2^{\mathrm{c}}$ & 0.5 & $<0.001$ \\
\hline $48 \mathrm{~h}$ & 266 & 27 & 0 & $9.0^{\mathrm{a}}$ & $8.6^{\mathrm{a}}$ & $8.4^{\mathrm{a}}$ & $1.8^{\mathrm{b}}$ & 0.3 & $<0.001$ \\
\hline $\left.72 h^{6}\right)$ & 471 & 47 & 2 & $4.8^{\mathrm{a}}$ & $4.7^{\mathrm{a}}$ & $4.8^{\mathrm{a}}$ & $1.3^{\mathrm{b}}$ & $0.03 \ldots 0.2$ & $<0.001$ \\
\hline \multicolumn{10}{|c|}{ Red clover (Rc) } \\
\hline $24 \mathrm{~h}$ & 179 & 32 & 89 & $10.7^{\mathrm{a}}$ & $9.9^{\mathrm{a}}$ & $9.8^{\mathrm{a}}$ & $1.6^{\mathrm{b}}$ & 0.5 & $<0.001$ \\
\hline $48 \mathrm{~h}$ & 209 & 24 & 26 & $11.1^{\mathrm{a}}$ & $10.9^{\mathrm{a}}$ & $11.0^{\mathrm{a}}$ & $2.0^{\mathrm{b}}$ & 0.2 & $<0.001$ \\
\hline $\left.72 h^{6}\right)$ & 333 & 35 & 11 & $7.5^{\mathrm{a}}$ & $7.7^{\mathrm{a}}$ & $7.3^{\mathrm{ab}}$ & $1.8^{\mathrm{b}}$ & $0.1 \ldots 0.9$ & 0.047 \\
\hline \multicolumn{10}{|c|}{ Mix of Lu/Grass } \\
\hline $24 \mathrm{~h}$ & 245 & 36 & 75 & $8.9^{\mathrm{a}}$ & $9.2^{\mathrm{a}}$ & $8.4^{\mathrm{a}}$ & $2.0^{\mathrm{b}}$ & 0.3 & $<0.001$ \\
\hline $48 \mathrm{~h}$ & 316 & 36 & 33 & $7.4^{\mathrm{a}}$ & $7.6^{\mathrm{a}}$ & $7.3^{\mathrm{a}}$ & $2.6^{\mathrm{b}}$ & 0.9 & 0.002 \\
\hline $\left.72 h^{6}\right)$ & 416 & 46 & 33 & $5.1^{\mathrm{b}}$ & $6.2^{\mathrm{a}}$ & $5.5^{\mathrm{b}}$ & $1.5^{\mathrm{c}}$ & 0.2 & $<0.001$ \\
\hline \multicolumn{10}{|c|}{ Mix of RC/Grass } \\
\hline $24 \mathrm{~h}$ & 211 & 39 & 107 & $8.9^{\mathrm{a}}$ & $8.7^{\mathrm{a}}$ & $8.6^{\mathrm{a}}$ & $1.6^{\mathrm{b}}$ & 0.3 & $<0.001$ \\
\hline $48 \mathrm{~h}$ & 284 & 35 & 51 & $10.9^{\mathrm{a}}$ & $10.9^{\mathrm{a}}$ & $10.8^{\mathrm{a}}$ & $1.3^{\mathrm{b}}$ & 0.3 & $<0.001$ \\
\hline $\left.72 h^{6}\right)$ & 440 & 49 & 30 & $6.3^{\mathrm{a}}$ & $6.8^{\mathrm{a}}$ & $5.4^{\mathrm{a}}$ & $1.0^{\mathrm{b}}$ & 0.3 & $<0.001$ \\
\hline \multicolumn{10}{|c|}{ Ester total (Ethyl acetate + Ethyl lactate) in mgkg-1DM } \\
\hline \multicolumn{10}{|l|}{$\begin{array}{l}\text { Lucerne } \\
\text { (Lu) }\end{array}$} \\
\hline $24 \mathrm{~h}$ & 232 & 28 & 39 & $142^{\mathrm{a}}$ & $129^{\mathrm{b}}$ & $126^{\mathrm{b}}$ & $0^{c}$ & 2.7 & $<0.001$ \\
\hline $48 \mathrm{~h}$ & 266 & 27 & 0 & $130^{\mathrm{ab}}$ & $129^{\mathrm{ab}}$ & п.а. $\left.{ }^{7}\right)$ & $0^{\mathrm{b}}$ & $6.5 \ldots 64.4$ & 0.003 \\
\hline $\left.72 h^{6}\right)$ & 471 & 47 & 2 & $155^{\mathrm{a}}$ & $126^{a}$ & $100^{\mathrm{b}}$ & $67^{\mathrm{b}}$ & $1.5 \ldots 16.9$ & 0.017 \\
\hline \multicolumn{10}{|c|}{ Red clover (Rc) } \\
\hline $24 \mathrm{~h}$ & 179 & 32 & 89 & $182^{\mathrm{a}}$ & $190^{\mathrm{a}}$ & $189^{a}$ & $0^{\mathrm{b}}$ & 5.8 & $<0.001$ \\
\hline $48 \mathrm{~h}$ & 209 & 24 & 26 & $166^{\mathrm{a}}$ & $171^{\mathrm{a}}$ & $168^{\mathrm{a}}$ & $0^{\mathrm{b}}$ & 2.8 & $<0.001$ \\
\hline $\left.72 h^{6}\right)$ & 333 & 35 & 11 & $148^{\mathrm{a}}$ & $177^{\mathrm{a}}$ & $143^{\mathrm{a}}$ & $0^{\mathrm{b}}$ & 27.6 & 0.008 \\
\hline \multicolumn{10}{|c|}{ Mix of Lu/Grass } \\
\hline $24 \mathrm{~h}$ & 245 & 36 & 75 & $189^{\mathrm{a}}$ & $137^{\mathrm{b}}$ & $119^{\mathrm{b}}$ & $83^{c}$ & 7.7 & $<0.001$ \\
\hline $48 \mathrm{~h}$ & 316 & 36 & 33 & $124^{\mathrm{a}}$ & $126^{\mathrm{a}}$ & $116^{\mathrm{b}}$ & $0^{c}$ & 1.3 & $<0.001$ \\
\hline $\left.72 h^{6}\right)$ & 416 & 46 & 33 & $130^{\mathrm{ab}}$ & $222^{\mathrm{a}}$ & $184^{\mathrm{a}}$ & $0^{\mathrm{b}}$ & 39.5 & 0.019 \\
\hline \multicolumn{10}{|c|}{ Mix of RC/Grass } \\
\hline $24 \mathrm{~h}$ & 211 & 39 & 107 & $191^{\mathrm{ab}}$ & $202^{\mathrm{a}}$ & $185^{\mathrm{b}}$ & $0^{c}$ & 2.5 & $<0.001$ \\
\hline $48 \mathrm{~h}$ & 284 & 35 & 51 & $197^{\mathrm{a}}$ & $206^{a}$ & $205^{\mathrm{a}}$ & $0^{\mathrm{b}}$ & 4 & $<0.001$ \\
\hline $\left.72 h^{6}\right)$ & 440 & 49 & 30 & $171^{\mathrm{a}}$ & $156^{\mathrm{a}}$ & $175^{\mathrm{a}}$ & $0^{\mathrm{b}}$ & 5.4 & $<0.001$ \\
\hline
\end{tabular}

$1) \mathrm{n}=3$; means within rows are significantly different if they have no letters in common $(P<0.05$, Tukey`s test).2)Dry matter in $\mathrm{g}$ kg-1FM 3 ) Fermentation coefficient $\mathrm{FC}=\mathrm{DM}(\%)+8 \mathrm{WSC} / \mathrm{BC} 4)$ Water soluble carbohydrates in $\mathrm{g} \mathrm{kg}-1 \mathrm{DM}$. 5)P-Values of global F-test.6)silage additives according DLG aim-of-acting 2, otherwise DLG $1 \mathrm{~b}$ (LAB1) or 1b, c (LAB 2).7) not analysed.

The legumes used in the trial were estimated as difficult (fermentation coefficient $\mathrm{FC}<35$ ) or moderate fermentable (FC 35-45) according to DLG (2011). Three EM with FC $>45$, all wilted for $72 \mathrm{~h}$, had DM contents over $400 \mathrm{~g} \mathrm{~kg}^{-1}$ and low levels of WSC. Although all EM were nitrate-free and thus with a higher risk for poor fermentation, butyric acid (BA) was only analysed in lucerne after $48 \mathrm{~h}$ of wilting and DM of $266 \mathrm{~g} \mathrm{~kg}^{-1}$ (data not shown). BA could be suppressed only with silage salt (WR 1a, DLG (2011)). Polyphenol oxidases (PPO), which occur in red clover [2], are able to inhibited proteolysis. On the other hand high levels of DM and therefore higheraw-values in combination with higher acidification rate can reduce clostridia activity [3]. The epiphytic content in our study was high (LAB from 6.9 to $8.6 \mathrm{log}$ cfug $^{-1} \mathrm{FM}$ ) and increased with wilting period. Lactic acid contents 
ranged between 49.8 and 104.5, acetic acid between 11.8 and $26.8 \mathrm{~g} \mathrm{~kg}^{-1} \mathrm{DM}$ (data not shown). Laboratory ensiling trials are characterised by clean experimental conditions that means free of clostridia spores. However, yeast counts (from 6.8 to $8.4 \mathrm{log}$ cfug $^{-1}$ FM) were high and increased during wilting period. In accordance to the fact that under anaerobic conditions yeasts are responsible for ethanol formation, the ethanol content in silages without additives was between 4.8 and $10.9 \mathrm{~g} \mathrm{~kg}^{-1} \mathrm{DM}$ (Table 1 ) with a strong negative correlation to $\mathrm{DM}$ content $\left(\mathrm{R}^{2}=0.81\right)$ and positive correlation to ester content $\left(R^{2}=0.65\right)$. The total esters ranged between 124 and $197 \mathrm{mg} \mathrm{kg}^{-1} \mathrm{DM}$ in untreated silages and consisted of only ethyl lactate. These ester contents are comparable with contents in grass silage considering the $\mathrm{pH}$ level between 4.0 and 6.3. As shown in Table 1 the contents of ethanol were mainly not affected by silage additives with LAB, the same applies for the contents of esters. The additive salts containing benzoate, nitrite and hexamine strongly reduced the ethanol and ester contents. According to Woolford [4] these substances are able to inhibited yeasts and possibly hetero fermentative LAB which also produce ethanol [5].

\section{Conclusion}

Ensiling within the lower DM range of legumes is associated with a higher risk of BA formation in lucerne. Elevated levels of ethanol, particularly in the lower range of DM, and esters occur in legume silages. For the reduction of ethanol and ester formation, chemical additives against yeasts and bacteria are necessary.

\section{References}

1. Weiss K, Auerbach H (2013) Volatile organic compounds (VOC) in grass silages. In: Michalk DL, Millar GD, Badgery WB, Broadfoot KM (Eds.), Proc. $22^{\text {nd }}$ Internatl Grassl Congress, Sydney, New South Wales, Australia, pp. 721-722.

2. Jones BA, Hatfield RD, Muck RE (1995) Screening Legume Forages for Soluble Phenols, Polyphenol Oxidase and Extract Browning. J Sci Food Agric 67(1): 109-112.

3. Kaiser E, Weiss K, Iv P (2009) The influence of dry matter, acidification and nitrate content on development of clostridia in silages from green forage. In: Broderick GA (Ed.), Proc of the XVth International Silage Conference. July 27-29, Madison, USA, pp. 247-248.

4. Woolford MK (1975) Microbiological Screening of Food Preservatives, Cold Sterilants and Specific Antimicrobial Agents as Potential Silage Additives. J Sci Food Agric 26(2): 229-237.

5. DLG (2011) Silierung. In: Praxishandbuch Futter- und Substratkonservierung.
Your next submission with Juniper Publishers will reach you the below assets

- Quality Editorial service

- Swift Peer Review

- Reprints availability

- E-prints Service

- Manuscript Podcast for convenient understanding

- Global attainment for your research

- Manuscript accessibility in different formats ( Pdf, E-pub, Full Text, Audio)

- Unceasing customer service

Track the below URL for one-step submission https://juniperpublishers.com/online-submission.php 